\title{
Examination of Relationship between Metacognitive Awareness, Problem Solving and Teacher Efficacy Perceptions of Physical Education and Sport Teachers
}

\author{
Soner Tuzcuoğlu ${ }^{1}$, A. Dilşad Mirzeoğlu ${ }^{2}$
}

\begin{abstract}
${ }^{1}$ Ahmet Barindirir Middle School, soner_tuzcuoglu@ @otmail.com
${ }^{2}$ Sakarya Applied Sciences University, belcesu@yahoo.com
\end{abstract}

Received: 08.04.2018

doi: 10.30655/besad.2018.7
Accepted: 21.05 .2018

Online Published: 30. 09. 2018 url: https://doi.org/10.30655/besad.2018.7

\begin{abstract}
The aim of this study was to examine the metacognitive awareness, problem solving and teacher efficacy perceptions of physical education and sport teachers in secondary schools in Turkey according to various demographic features and to examine the relationship between these variables. In this study, 133 male (80.12\%) and 33 female (17.88\%) physical education and sport teachers, who were working in government secondary schools in spring term of 2016-2017 academic year, voluntarily participated in the study. Metacognitive Awareness Inventory, which was developed by Schraw and Dennison (1994) and was translated in Turkish by Akı, Abacı and Çetin, Problem Solving Inventory which was developed by Heppner and Petersen (1982) and was translated in Turkish by Şahin, Şahin and Heppner (1993) and Teachers Sense of Efficacy Scale which was developed by Tschannen-Moran and Woolfolk-Hoy (2001) and was translated in Turkish by Çapa, Çakıroğlu and Sarlkaya (2005) were used to collect the data. Percentage, frequency, independent samples t-test, one-way analysis of variance and Pearson productmoment correlation coefficient statistical techniques were used for data analysis. Analyses of the data revealed that the physical education and sport teachers had a high metacognitive awareness level and teacher efficacy perception and their problem solving perception is at the medium level. There was no significant difference between the sub-dimensions of their metacognitive awareness level, problem solving and efficacy perception of teachers according to the gender, experience and education level. It is mentioned that there was a medium level, meaningful and positive relationship between sub-dimensions of teacher efficacy perception and sub-dimensions of metacognitive awareness but there was no relationship between metacognitive awareness and problem solving. Also, there was a low, meaningful and positive relationship between teacher efficacy and problem solving perceptions.
\end{abstract}

Keywords: Metacognitive awareness, problem solving, teacher efficacy, physical education and sports teacher.

\section{Beden Eğitimi ve Spor Öğretmenlerinin Bilişötesi Farkındalık, Problem Çözme ve Öğretmenlik Öz-yeterlik Algıları Arasındaki İlişsinin İncelenmesi}

Öz

Bu çalışmanın amacı ortaokulda görev yapan beden eğitimi ve spor öğretmenlerinin bilişötesi farkındalık, problem çözme ve ögretmenlik özyeterlik algllarını çeşitli değişkenlere göre incelemek ve bu özellikler arasındaki ilişkiyi tespit etmektir. Çalışmaya 2016-2017 eğitim-öğretim yılı bahar döneminde Milli Ĕ̈itim Bakanlı̆̆ tarafindan düzenlenen bir çallştaya davet edilen ve devlet ortaokullarda görev yapan 133 erkek (\%80.12) ve 33 kadın (\%17.88) beden eğitimi ve spor ögretmeni gönüllü olarak katılmuștır. Çalışmada veri toplamak için Schraw ve Dennison (1994) tarafindan geliştirilen, Akın, Abacı ve Çetin (1997) tarafindan Türkçe'ye uyarlama çalışması yapılan “Bilişötesi Farkındalık Envanteri”, Heppner ve Petersen (1982) tarafindan geliştirilen, Şahin, Şahin ve Heppner (1993) tarafindan Türkçe'ye uyarlanan 
"Problem Çözme Envanteri" ve Tschannen- Moran ve Woolfolk-Hoy (2001) tarafindan gelistirilen ve Türkçe'ye uyarlama çalışması Çapa, Çakıroğlu ve Sarıkaya (2005) tarafindan yapılan "Öğretmen Özyeterlik Ölçeği”" kullanılmıştır. Araştırmada elde edilen verilerin çözümlenmesinde, yüzde, frekans, bağımsız gruplar t testi, tek yönlü varyans analizi ve Pearson Momentler Çarpımı Korelasyon katsayısı istatistiksel teknikleri kullanılmıştır. Araşstırmada elde edilen bulgulara göre, çalışmaya katılan beden eğitimi ve spor öğretmenlerinin bilişötesi farkındalı düzeylerinin ve ögretmen özyeterlik algılarının oldukça yüksek, problem çözme algılarının ise orta düzeyde olduğu belirlenmiştir. Çalı̧̧maya katılan ögretmenlerinin cinsiyetlerine, kıdem yillarına ve eğitim seviyelerine göre, bilişötesi farkındalık düzeylerinin, problem çözme ve ögretmen özyeterlik algılarının hiçbir alt boyutunda anlamlı farklılığa ulaşılamamıştır. Çalışma bulguları, bilişötesini oluşturan alt boyutlar ile öğretmen özyeterlik algısını oluşturan alt boyutlar arasında orta düzeyde, anlamlı ve pozitif ilişsiler olduğunu, ancak bilişötesi farkındalık ile problem çözme algısı arasında ilişki olmadı̆̆ını ortaya koymuştur. Ayrıca, öğretmen özyeterlik algısı ile problem çözme algısı arasında da düşük, anlamlı ve pozitif ilişkiler bulunmuştur.

Anahtar kelimeler: Bilişötesi farkındalık, problem çözme, öz yeterlik, beden eğitimi ve spor ögretmeni.

\section{Giriş}

Son dönemlerde eğitim alanında yapılan çalışmalarda öğrenme-öğretme sürecinin öğrenen sorumluluğunda olması önem kazanmıştır. Çünkü öğrenme kişiye özgüdür ve bireyler öğrenirken kendilerine özgü yöntemler kullanırlar, aynı zamanda kendi öğrenmelerini kontrol ederler. Bireyin öğrenme sırasında gerçekleştirdiği bilişsel süreçlerin ve stratejilerin farkında olması ve öğrenmesini yönlendirmesi bilişötesi (metacognition) kavramı ile açıklanmaktadır. Bilişötesi ile ilk çalışmaları yapan Flavell (1979)' in tanımıyla bilişötesi anlamayı izleme ve özdenetimi de içerecek biçimde kişinin kendi bilişsel süreçlerinin farkında olması ve bunları kontrol edebilmesidir. Kendi zihinsel faaliyetlerini izleyebilme, gözlemleyebilme ve öğrenmenin özdenetimi gibi yetenekler bilişötesi becerileri oluşturmaktadır. Schraw ve Dennison (1994), bilişötesini kişinin düşünme, anlama ve kendi öğrenmesini kontrol etme yeteneği olarak; bireyin kendi performansını direk olarak yükseltecek bir yolda planlama, sıralama, izleme ve daha iyi uygulama yetisini ise bilişötesi farkındalık olarak tanımlar. Biliş ötesi beceriler birey tarafından düşünmeyi ve öğrenmeyi düzenlemek için kullanılırken (Karakelle ve Saraç, 2007), öğrenmenin düzenlenme sürecinde yer alan planlama, izleme ve değerlendirme becerilerini içermektedir (Vrieling, Bastianes ve Stijnen, 2012).

Bilişötesi farkındalık; düşünme üstü öz düzenlemenin kontrolünü yapabilir ve öğrenme süreci ile üretiminde etkili olur (Hartman, 1998). Bilişötesi becerilerin kişinin bir şeyi anlamasına ve bilişsel yeteneğini kontrol etmesine yardımcı olduğundan dolayı öğrencilerin bilişötesi becerilerinin olabildiğince erken eğitilmelidir (Siswati ve Corebima, 2017). Bu anlamda bilişötesine ağırlık veren (Gürleyük ve Sucu, 2014); öz yeterlik ve bilişötesi arasında anlamlı ilişkilerin olduğu (Sapancı, 2010); bilişötesi ve problem çözmenin sonuçlarının birbirini etkilediğini (Kışkır, 2011; Demirel ve Turan, 2010; Kiremitçi, 2011; Özsoy, 2007; Yurdakul, 
2004; Borkowski, Estrada, Mistead ve Hale, 1989; Goos ve Galbraith, 1996) gösteren çalışmalara rastlanmaktadir.

Öğrenme sürecinde ortaya çıkan problemlerin çözülerek eğitimin kalitesini arttırmak için öğrencilerin bilişötesi becerilerinin erken yaşlardan itibaren geliştirilmesi gerekmektedir. Öğretmenler öğrencilerin etkili birer öğrenici olmaları için derslerini planlama ve sunma esnasında öğrencilerinde öğrenmenin nasıl meydana geldiğini göz önünde bulundurmak zorundadırlar (Akın, 2006). Bilişötesi beceriler öğrencilere öğretilecek dersler olarak değil belli konulara entegre edilerek verilmelidir (Pintrich, 2002). Ayrıca öğretmenler hem bilişsel hem de üst bilişsel beceriler için öğrencilere örnek olmaktadırlar. Öğretmenlerin bilişsel ötesi farkındalıklarının net olması öğrencilerin bilişsel ve bilişötesi becerilerini geliştirme ihtimallerini artırır (Schunk, 1989). Öğretmenlerin bilişötesi farkındalık düzeylerinin öğrencilerin bilişötesi becerilerinin gelişmesinde önemli bir faktör olduğu düşünülürse, öğretmenlerin bu farkındalığa sahip olma düzeyleri ve bu farkındalığın başka becerilerle etkileşim içinde olup olmadığını incelemek önemli olmaktadır.

Dewey'e göre problem, insan zihnini karıştıran, ona meydan okuyan ve inancı belirsizleştiren her şey olarak tanımlar (Gelbal, 1991). Problem çözme ise; en basit haliyle bir amaca ulaşmak için engelleri aşma ve çare bulma süreci olarak ifade edilebilir (Morgan, 1999). Problem çözme, bireyin karşılaştığı güçlükleri yenmek için zihinde oluşturduğu bilişsel süreçler yardımıyla çevredeki kaynakları işe koşarak, içinde bulunulan durumu kendi lehine çevirme faaliyetidir (Şara, 2012). Problem çözme becerisi, bir problemle karşılaşıldığında onu sınırlayıp anlayabilme, çözümü için uygun yöntemi seçme, bu yöntemi kullanma ve sonuçları analiz etme yeteneklerinden oluşmaktadır. Bu süreçte birey üst düzey düşünme becerilerini işe koşması gerekmektedir. Değişik problemlerin üstesinden gelmek isteyen bir bireyin yaratıcı, yansıtıcı, eleştirel ve analitik düşünebilme yeteneklerine sahip olması gerekir. (Bilen, 1999). Bireylerin içinde yaşadıkları çevreye etkin bir uyum sağlayabilmeleri için problem çözmeyi öğrenmeleri gerekmektedir. Hayatta karşımıza çıkan bazı problemlerin doğru ve kesin cevapları varken bazılarının da çözümleri kesin değildir. Bu problemlerin çözümü, disiplinler arası bilgiyi, çok yönlü düşünmeyi ve yaratıcılığı gerektirir (Senemoğlu, 1997). Bu açıdan bakıldığında problem çözme becerisi, kişisel gelişim, etkili öğrenme becerisi yüksek, yaratıcı ve bağımsız düşünebilen, sosyal ve kendine güvenen bireylerin yetişmesini sağlayan bir beceri olarak karşımıza çıkmaktadır (Miller ve Nunn, 2011). Problem çözme becerisini geliştirmiş bireylerin oluşturduğu bir toplum, bu becerilerini etkin bir şekilde, karşılaştıkları problemleri çözmeye sahip bireyler yetiştirmeye kullanacaktır. Bir toplumdaki bireylere problem çözme becerisini kazandıran 
önemli unsurlardan biri de okul ve öğretmenlerdir. Bu açıdan düşünüldügünde öğretmenlerin bu beceriye ne düzeyde sahip olduklarını anlamak önemli görülmektedir. Çünkü problem çözme becerisi düşük olan öğretmenlerin sınıf içinde ve dışında öğrencilerin bilişötesi becerilerinin gelişimine yönelik uygun aktiviteler yapmalarını beklemek gerçekçi bir yaklaşım olmayacaktır. Bireyin bir problemin üstesinden gelmesinde özellikle öz düzenlemeye dayalı öğrenmenin alt boyutlarından olan öz yeterlik algıs1 etkilidir (Kruger, 1997). Öz yeterlik alg1s1, bireylerin olas1 durumlarla başa çıkabilmek için gerekli olan eylemleri ne kadar iyi yapabileceklerine (Bandura, 1982) ve belli bir performansı göstermek için gerekli etkinlikleri organize ederek yapma kapasitelerine ilişkin inançlarıdır (Bandura, 1986). Öz yeterlik inancı her meslekte olduğu gibi öğretmenlikte de başarının anahtarlarından birisidir. Bu bağlamda, Schriver ve Czerniak (1999) öğretmene ilişkin olarak öz yeterlik algısını öğretmenin, öğrencinin başarı düzeyi ve davranışlarında olumlu yönde değişiklikler meydana getirmesi ile ilgili olarak kendi öğretme yeteneğine olan inancı olarak tanımlamışlardır. Öğretmen öz yeterliği kavramı öğretmenin “görevlerimi yerine getirmek için gerekli düşünceleri ve eylemleri planlayıp uygulayabilir miyim?" sorusuna verdiği cevap olarak tanımlamaktadır. Dolayısıyla bu kavram; öğretmenliğin gerektirdiği görev ve sorumlulukları yerine getirebilmek için sahip olunması gereken bilgi, beceri ve tutumları vurgulamaktadır (Goddard, Hoy ve Woolfolk-Hoy, 2004). Tschannen-Moran ve Woolfolk-Hoy (2001) ise öğretmen öz yeterliğini, öğretmenin öğretmeyi başarılı bir şekilde yerine getirebilmeye karşı inançları olarak tanımlamaktadır. Öğretmenlerin öz yeterlik inançları öğretime harcadıkları çaba, hedef ve istek düzeylerini etkilemektedir. Bu nedenle öz yeterliği yüksek ve düşük olan öğretmenler arasında sınıf düzeni, yeni yöntemler kullanma, öğrenme zorluğu çeken öğrencilere dönütler gibi konularda farklılaşmalar olmakta ve bu farklılıklarda hitap ettikleri öğrenci motivasyonu ve başarısı üzerinde etki yaratmaktadır (Özkan, Tekkeya, ve Çakıroğlu, 2002). Bu nedenle iyi yetişmiş öğretmenlerin yüksek öz yeterlik inancına sahip olmaları beklenmektedir.

Toplumların gereksinim duydukları insan gücünü yetiştirerek, yaşam kalitesini yükseltecek olan öğretmenlerin, karşılaştıkları sorunlara olası çözüm yolları üretebilmek için kendi düşünme süreçlerini sürekli kontrol ederek ve değerlendirerek stratejiler geliştiren, bu stratejileri uygulama konusunda kendine güvenen ve bu süreçte sabırlı olan bireyler olmaları gerekmektedir. Güncellenen eğitim programları içerisinde (MEB, 2018), öğrencilerin zekâ seviyeleri, bilişötesi farkındalık becerileri, problem çözme beceri düzeylerinin tespiti ve bu becerilerin geliştirilmesi amacıyla izlenecek olan öğretim stratejilerinin planlanması ve uygulanmasının önemi daha da çok artmıştır. Buradan hareketle farklı sosyal ortamlarda, değişik özelliklerdeki spor alanlarında 
ve okullarda görev alan beden eğitimi ve spor öğretmenlerin bilişötesi farkındalık düzeyleri, problem çözme seviyeleri ve kendi öğretmenlik öz yeterlik algılarının belirlenmesi ve bu yapılar arasındaki ilişkilerin incelenerek öğretmenlerin bu konudaki yeterliklerinin açığa çıkarılması, hem eğitim sisteminde görev yapan beden eğitimi ve spor öğretmenlerine dönüt sunmak, hem de bundan sonra yetiştirilecek olan aday beden eğitimi ve spor öğretmenleri için gerekli tedbirlerin alınmasını açısından önemli görülmüştür. Nitekim Aktağ, Şemşek ve Tuzcuoğlu (2017)’nun beden eğitimi öğretmenleri üzerinde yapmış oldukları çalışmada bilişötesi farkındalık becerilerinin planlama alt boyutunda tecrübeli öğretmenlerin daha az tecrübeli öğretmenlere göre daha fazla bilişötesi farkındalığa sahip olduklarını belirtmişlerdir. Bu nedenle bu araştırmanın amacı ortaokullarda çalışan beden eğitimi ve spor öğretmenlerinin bilişötesi farkındalık, problem çözme ve öğretmen öz-yeterlik algı düzeylerinin belirlenerek, bu özellikler arasındaki ilişkinin ne düzeyde olduğunu belirlemektir.

\section{Yöntem}

Bu çalışmada ilişkisel (korelasyonel) araştırma deseni kullanılmıştır.

\section{Çalışma Grubu}

Araştırma grubunun belirlenmesinde benzeşik örnekleme yöntemi kullanılmıştır. Araştırmada veri elde etmek üzere kullanılan ölçekler 2016-2017 eğitim-öğretim yılı bahar döneminde Milli Eğitim Bakanlığı'nın (MEB) devlet ortaokullarında görev yapan beden eğitimi ve spor öğretmenlerine yönelik olarak MEB tarafından düzenlenen ve Türkiye'nin tüm illerinden 3'er öğretmenin katıldığı çalıştayda araştırmacılar tarafından dağıtılmış ve öğretmenlerden gönüllü olanlar envanteri doldurduktan sonra toplanmıştır. Çalışmaya katılan öğretmenlerin demografik özellikleri tablo 1'de verilmiştir.

Tablo 1. Çalışmaya katılan öğretmenlerin demografik özellikleri

\begin{tabular}{ccccccc}
\hline Değişken & Kadın & \multicolumn{3}{c}{ Erkek } & \multicolumn{3}{c}{ Toplam } \\
\hline Kıdem & f & \% & f & \% & f & \% \\
\hline $1-5$ yıl & 8 & 4.8 & 22 & 13.3 & 30 & 18.1 \\
$6-10$ yıl & 8 & 4.8 & 33 & 19.9 & 41 & 24.7 \\
$11-15$ yıl & 5 & 3.0 & 42 & 25.3 & 47 & 28.3 \\
$16-20$ yıl & 7 & 4.2 & 23 & 13.9 & 30 & 18.1 \\
21 ve üstü & 5 & 3.0 & 13 & 7.8 & 18 & 10.8 \\
Toplam & 33 & 19.9 & 133 & 80.1 & 166 & 100 \\
\hline Eğitim Durumu & $\mathbf{f}$ & $\mathbf{\%}$ & $\mathbf{f}$ & $\mathbf{\%}$ & $\mathbf{f}$ & $\mathbf{\%}$ \\
\hline Lisans & 28 & 16.9 & 112 & 67.5 & 140 & 84.3 \\
Yüksek Lisans & 5 & 3.0 & 21 & 12.7 & 26 & 15.7 \\
Toplam & 33 & 19.9 & 133 & 80.1 & 166 & 100 \\
\hline
\end{tabular}


Tablo 1'de görüldüğü gibi, çalışmaya 2016-2017 eğitim-öğretim yılı bahar döneminde devlet ortaokullarda görev yapan 133 erkek (\%80.12) ve 33 kadın (\%17.88) beden eğitimi ve spor öğretmeni gönüllü olarak katılmıştır. Erkek öğretmenlerin \% 13.3'ü 1-5 yıl, \% 19.9'u 6-10 yıl, \% 25.3’ü 11-15 yıl, \% 13.9'u 16-20 yıl ve \% 7.8'i 21 ve üstü mesleki kıdeme sahipken, kadın öğretmenlerin \% 4.8'i 1-5 y1l, \% 4.8'i 6-10 yıl, \% 3'ü 11-15 yıl, \% 4.2'si 16-20 y1l ve \% 3'ü 21 ve üstü mesleki kıdeme sahiptir. Çalışmaya katılan öğretmenlerin \%84.3'ü lisans, \% 15.7'si ise yüksek lisans mezunudur.

\section{Veri Toplama Araçları}

Araştırmada veri toplamak amacı ile biliş ötesi farkındalık envanteri, problem çözme envanteri ve öğretmen öz-yeterlik ölçeği kullanılmıştır.

Biliş Ötesi Farkındalık Envanteri: Schraw ve Dennison (1994) tarafından biliş ötesi farkındalık düzeyini ölçmek amacıyla geliştirilen ölçek, Akın, Abacı ve Çetin (2007) tarafından Türkçeye uyarlanmıştır. Ölçek beşli Likert yapısında 52 maddeden oluşmaktadır. Ölçek temelde iki alt boyut ve alt boyutlara bağlı toplam sekiz alt faktörden oluşmaktadır: Bilişin bilgisi boyutu; açıklayıcı bilgi, prosedürel bilgi ve durumsal bilgi olmak üzere üç alt boyut içermektedir. Bilişin düzenlemesi boyutu ise planlama, izleme, değerlendirme, hata ayıklama ve bilgi yönetme olmak üzere beş alt boyut içermektedir. Envanterden alınabilecek en yüksek puan 260, en düşük puan ise 52 'dir. Buna göre kişinin biliş ötesi farkındalık düzeyi, envanterden alınan genel puan 2,5'in altındaysa düşük, 2,5 puanın üstündeyse yüksek olarak nitelenmektedir (Akın, 2007). Ölçeğin Türkçe formuna uyarlanması ile birlikte elde edilen iç tutarlılık güvenirlik katsayısı, ölçeğin tümü için 0,95 'tir.

Problem Çözme Envanteri: Heppner ve Petersen (1982) tarafından bireylerin problem çözme becerilerini belirlemek amacıyla geliştirilen ölçek; Şahin, Şahin ve Heppner tarafindan (1993) tarafından Türkçeye uyarlanmıştır. Ölçek altılı likert yapısında 35 maddeden oluşmaktadır. Ölçekten alınan puanlar yükseldikçe birey, problem çözme becerileri konusunda kendini yetersiz olarak algılamaktadır (Turan, 2010). Ölçeğin puan aralığı 32-192'dir. Hesaplama sonrası alınan 32 ile 85 arasındaki puanlar yüksek, 86 ile 138 arasındaki puanlar orta, 139 ile 192 arasındaki puanlar düşük problem çözme becerisi olarak değerlendirilmektedir (Şahin, 1993). Ölçek “aceleci yaklaşım”, “düşünen yaklaşım”, “kaçıngan yaklaşım”, "değerlendirici yaklaşım”, "kendine güvenli yaklaşım” ve "planlı yaklaşım” olarak 6 faktörden oluşurken iç tutarlılık güvenirlik katsayısı 0,88 bulunmuştur. Alt boyutlara ait Cronbach Alpha katsayıları sırasıyla.74, .73, .72, .66, .76 ve .69 olarak hesaplanmıştır (Tavşancıl, 2006).

Öğretmen Öz-yeterlik Ölçeği: Araştırmada kullanılan öğretmen öz-yeterlik ölçeği, Tschannen-Moran ve Woolfolk-Hoy (2001) tarafından geliştirilmiş, Türkçe geçerlik ve 
güvenilirlik çalışması Çapa, Çakıroğlu ve Sarıkaya (2005) tarafından yapılmıştır. Öz-yeterlik ölçeği toplam 24 madde ve üç alt boyuttan oluşmaktadır. Güvenilirlik çalışması sonucu ölçeğin Cronbach Alfa iç tutarlılık katsayıları, öğrenci katılımını sağlama alt boyutu için .82, sınıf yönetimi alt boyutu için .84 , öğretim stratejileri alt boyutu için .86 ve ölçeğin geneli için “.93” olarak bulunmuştur. Ölçek Likert tipinde “yetersiz” (1) ile “çok yeterli” (9) olmak üzere dokuzlu olarak derecelendirilmiştir. Ölçekten alınabilecek en düşük puan 24, en yüksek puan ise 216 ' dir.

\section{Verilerin Analizi}

Araştırmada elde edilen verilerin çözümlenmesinde parametrik veya non-parametrik testlerden hangisinin kullanılacağına karar vermek üzere toplanan verilerin normal dağılım özelliğine Kolmogorov Smirnov ve varyanslarının homojenlik durumuna Levene testi yapılarak bakılmıştır. Yapılan analizler sonucunda verilerin normal dağglım özelliğine sahip ve varyansların da homojen olduğu belirlenmiş ve çalışmada parametrik istatistik yapılmasına karar verilmiştir. $\mathrm{Bu}$ nedenle araştırmada elde edilen verilerin çözümlenmesinde, yüzde, frekans, bağımsız gruplar $\mathrm{t}$ testi, tek yönlü varyans analizi ve Pearson Momentler Çarpımı Korelasyon katsayısı istatistiksel teknikleri kullanılmıştır. Araştırmada anlamlılık düzeyi .05 olarak belirlenmiştir.

\section{Bulgular}

Tablo 2. Öğretmenlerin bilişötesi farkındalık düzeylerine ilişkin aritmetik ortalama ve standart sapma oranları

\begin{tabular}{lccc}
\hline \multicolumn{1}{c}{ Alt-boyutlar/Boyutlar } & $\mathbf{N}$ & $\overline{\mathbf{X}}$ & Sd \\
\hline Açıklayıcı bilgi & 166 & 4.30 & .44 \\
Prosedürel bilgi & 166 & 4.06 & .53 \\
Durumsal bilgi & 166 & 4.32 & .47 \\
Planlama & 166 & 4.20 & .50 \\
İzleme & 166 & 4.16 & .52 \\
Değerlendirme & 166 & 4.23 & .52 \\
Hata ayıklama & 166 & 4.22 & .57 \\
Bilgi yönetme & 166 & 4.19 & .50 \\
Bilişin bilgisi & 166 & 4.23 & .43 \\
Bilişin düzenlenmesi & 166 & 4.20 & .47 \\
Biliş ötesi & 166 & 4.21 & .44 \\
\hline
\end{tabular}


Tablo 3. Öğretmenlerin mesleki özyeterlik algılarına ilişkin aritmetik ortalama ve standart sapma oranları

\begin{tabular}{lccc}
\hline \multicolumn{1}{c}{ Alt-boyutlar } & N & $\overline{\mathbf{X}}$ & Sd \\
\hline Katılımı sağlama & 166 & 7.59 & 1.08 \\
Sınıf yönetimi & 166 & 7.80 & .89 \\
Öğretim stratejileri & 166 & 7.87 & 1.23 \\
\hline
\end{tabular}

Tablo 4. Öğretmenlerin problem çözme algılarına ilişkin aritmetik ortalama ve standart sapma oranlar1

\begin{tabular}{lccc}
\hline \multicolumn{1}{c}{ Alt-boyutlar } & $\mathbf{N}$ & $\overline{\mathbf{X}}$ & Sd \\
\hline Aceleci yaklaşım & 166 & 2.60 & .97 \\
Düşünen yaklaşım & 166 & 3.85 & .92 \\
Kaçıngan yaklaşım & 166 & 2.11 & 1.65 \\
Değerlendirici yaklaşım & 166 & 3.75 & 1.17 \\
Kendine güvenli yaklaşım & 166 & 3.71 & .87 \\
Planlı yaklaşım & 166 & 3.88 & .99 \\
Toplam & 166 & 3.31 & .64 \\
\hline
\end{tabular}

Tablo 2, 3 ve 4 incelendiğinde, çalışmaya katılan beden eğitimi ve spor öğretmenlerinin biliş

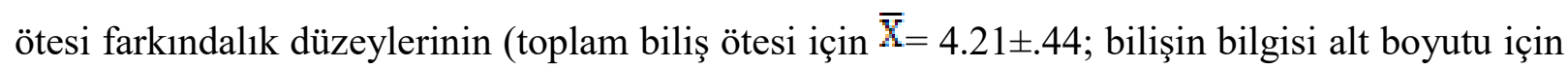
$\bar{X}_{=} 4.23 \pm .43$; bilişin düzenlenmesi alt boyutu için $\left.\bar{X}_{=} 4.20 \pm .47\right)$ ve öğretmen öz yeterlik algılarının (öğrenci katılımını sağlama alt boyutu için $\overline{\mathrm{X}}=7.59 \pm 1.08$, sınıf yönetimi alt boyutu için $\bar{X}=7.80 \pm .89$ ve öğretim stratejileri alt boyutu için $\bar{X}_{=} 7.87 \pm 1.23$ ) yüksek düzeyde olduğu, problem çözme becerilerinin ise orta düzeyde (toplam problem çözme $\bar{X}=3.31 \pm .64$; aceleci yaklaşım alt boyutu için $\bar{X}=2.60 \pm .97$; düşünen yaklaşım alt boyutu için $\bar{X}=3.85 \pm .92$; kaçıngan yaklaşım alt boyutu için $\bar{X}=2.11 \pm 1.65$; değerlendirici yaklaşım alt boyutu için $\bar{X}=3.75 \pm 1.17$; kendine güvenli yaklaşım alt boyutu için $\bar{X}=3.71 \pm .87$ ve planlı yaklaşım alt boyutu için $\bar{X}=$ $3.88 \pm .99)$ olduğu belirlenmiştir. 
Tablo 5. Cinsiyete göre öğretmenlerin bilişötesi farkındalık, öğretmen özyeterlik ve problem çözme algılarının karşılaştırılması

\begin{tabular}{|c|c|c|c|c|c|c|c|c|}
\hline & Alt-boyutlar & Cinsiyet & $\mathbf{N}$ & $\overline{\mathrm{X}}$ & Sd & SD & $\mathbf{t}$ & $\mathbf{p}$ \\
\hline \multirow{20}{*}{$\begin{array}{l}\text { Bilişötesi } \\
\text { Farkındalık }\end{array}$} & Açıklayıcı bilgi & Kadın & 33 & 4.33 & .41 & 164 & -.416 & .678 \\
\hline & & Erkek & 133 & 4.29 & .44 & & & \\
\hline & Prosedürel bilgi & Kadın & 33 & 4.00 & .59 & 164 & .808 & .420 \\
\hline & & Erkek & 133 & 4.08 & .51 & & & \\
\hline & Durumsal bilgi & Kadın & 33 & 4.33 & .50 & 164 & -.191 & .849 \\
\hline & & Erkek & 133 & 4.32 & .46 & & & \\
\hline & Planlama & Kadın & 33 & 4.30 & .51 & 164 & -1.218 & .225 \\
\hline & & Erkek & 133 & 4.89 & .04 & & & \\
\hline & İzleme & Kadın & 33 & 4.24 & .43 & 164 & -.967 & .335 \\
\hline & & Erkek & 133 & 4.14 & .54 & & & \\
\hline & Değerlendirme & Kadın & 33 & 4.29 & .56 & 164 & -.791 & .430 \\
\hline & & Erkek & 133 & 4.21 & .51 & & & \\
\hline & Hata ayıklama & Kadın & 33 & 4.32 & .54 & 164 & -1.154 & .250 \\
\hline & & Erkek & 133 & 4.19 & .58 & & & \\
\hline & Bilgi yönetme & Kadın & 33 & 4.20 & .51 & 164 & -.152 & .880 \\
\hline & & Erkek & 133 & 4.18 & .50 & & & \\
\hline & Bilişin bilgisi & Kadın & 33 & 4.22 & .43 & 164 & .119 & .905 \\
\hline & & Erkek & 133 & 4.23 & .43 & & & \\
\hline & Bilişin & Kadın & 33 & 4.26 & .45 & 164 & -.957 & .348 \\
\hline & düzenlenmesi & Erkek & 133 & 4.18 & .48 & & & \\
\hline \multirow{6}{*}{$\begin{array}{l}\text { Mesleğe } \\
\text { Yönelik } \\
\text { Öz yeterlik }\end{array}$} & Katılımı sağlama & Kadın & 33 & 7.75 & .94 & 164 & -.932 & .353 \\
\hline & & Erkek & 133 & 7.55 & 1.11 & & & \\
\hline & Sınıf yönetimi & Kadın & 33 & 7.90 & .98 & 164 & -.730 & .466 \\
\hline & & Erkek & 133 & 7.77 & .87 & & & \\
\hline & Öğretim stratejileri & Kadın & 33 & 7.85 & .97 & 164 & .087 & .931 \\
\hline & & Erkek & 133 & 7.87 & 1.29 & & & \\
\hline \multirow{12}{*}{$\begin{array}{l}\text { Problem } \\
\text { Çözme }\end{array}$} & Aceleci yaklaşım & Kadın & 33 & 2.49 & .97 & 164 & .751 & .475 \\
\hline & & Erkek & 133 & 2.63 & .98 & & & \\
\hline & Düşünen yaklaşım & Kadın & 33 & 3.79 & 1.08 & 164 & .386 & .700 \\
\hline & & Erkek & 133 & 3.86 & .87 & & & \\
\hline & Kaçıngan yaklaşım & Kadın & 33 & 1.99 & 1.76 & 164 & .456 & .649 \\
\hline & & Erkek & 133 & 2.14 & 1.63 & & & \\
\hline & Değerlendirici & Kadın & 33 & 3.79 & 1.21 & 164 & -.212 & .833 \\
\hline & yaklaşım & Erkek & 133 & 3.74 & 1.70 & & & \\
\hline & Kendine & Kadın & 33 & 3.45 & .82 & 164 & 1.808 & .059 \\
\hline & yaklaşım & Erkek & 133 & 3.77 & 1.17 & & & \\
\hline & Planlı & Kadın & 33 & 3.93 & 1.17 & 164 & -.366 & .715 \\
\hline & yaklaşım & Erkek & 133 & 3.86 & .95 & & & \\
\hline
\end{tabular}

Tablo 5'de görüldüğü gibi çalışmaya katılan öğretmenlerin cinsiyetlerine göre biliş ötesi farkındalık düzeylerini, problem çözme becerilerini ve öğretmen öz yeterlik algılarını oluşturan hiçbir alt boyutta anlamlı farklılığa ulaşılamamıştır $(\mathrm{p}>0.05)$. 
Tablo 6. Kıdem yılı değişkenine göre öğretmenlerin bilişötesi farkındalık düzeylerinin karşıllaştırılması

\begin{tabular}{|c|c|c|c|c|c|c|}
\hline Alt Boyutlar & $\begin{array}{l}\text { Varyansın } \\
\text { Kaynağı }\end{array}$ & $\begin{array}{l}\text { Kareler } \\
\text { Toplamı }\end{array}$ & SD & $\begin{array}{c}\text { Kareler } \\
\text { Ortalaması }\end{array}$ & $\mathbf{F}$ & $\mathbf{p}$ \\
\hline \multirow[t]{3}{*}{ Açıklayıcı bilgi } & Gruplar aras1 & 1.213 & 4 & .303 & 1.620 & .172 \\
\hline & Gruplar içi & 30.133 & 161 & .187 & & \\
\hline & Toplam & 31.346 & 165 & & & \\
\hline \multirow[t]{3}{*}{ Prosedürel bilgi } & Gruplar aras1 & 1.091 & 4 & .273 & .985 & .417 \\
\hline & Gruplar içi & 44.555 & 161 & .277 & & \\
\hline & Toplam & 45.646 & 165 & & & \\
\hline \multirow[t]{3}{*}{ Durumsal bilgi } & Gruplar arası & 1.599 & 4 & .400 & 1.845 & .123 \\
\hline & Gruplar içi & 34.880 & 161 & .217 & & \\
\hline & Toplam & 36.478 & 165 & & & \\
\hline \multirow[t]{3}{*}{ Planlama } & Gruplar aras1 & .775 & 4 & .194 & .786 & .536 \\
\hline & Gruplar içi & 39.691 & 161 & .247 & & \\
\hline & Toplam & 40.466 & 165 & & & \\
\hline \multirow[t]{3}{*}{ İzleme } & Gruplar arası & .955 & 4 & .239 & .884 & .475 \\
\hline & Gruplar içi & 43.478 & 161 & .270 & & \\
\hline & Toplam & 44.433 & 165 & & & \\
\hline \multirow[t]{3}{*}{ Değerlendirme } & Gruplar aras1 & .606 & 4 & .151 & .557 & .694 \\
\hline & Gruplar içi & 43.751 & 161 & .272 & & \\
\hline & Toplam & 44.357 & 165 & & & \\
\hline \multirow[t]{3}{*}{ Hata ayıklama } & Gruplar arası & 1.597 & 4 & .399 .328 & 1.218 & .305 \\
\hline & Gruplar içi & 52.788 & 161 & & & \\
\hline & Toplam & 54.380 & 165 & & & \\
\hline \multirow[t]{3}{*}{ Bilgi yönetme } & Gruplar aras1 & .969 & 4 & .242 & .960 & .431 \\
\hline & Gruplar içi & 40.612 & 161 & .252 & & \\
\hline & Toplam & 41.581 & 165 & & & \\
\hline \multirow[t]{3}{*}{ Bilişin bilgisi } & Gruplar arası & .893 & 4 & .233 & 1.235 & .298 \\
\hline & Gruplar içi & 29.114 & 161 & .181 & & \\
\hline & Toplam & 30.007 & 165 & & & \\
\hline \multirow{3}{*}{$\begin{array}{l}\text { Bilişin } \\
\text { düzenlenmesi }\end{array}$} & Gruplar aras1 & .766 & 4 & .192 & .861 & .489 \\
\hline & Gruplar içi & 35.808 & 161 & .222 & & \\
\hline & Toplam & 36.575 & 165 & & & \\
\hline
\end{tabular}

Tablo 6 incelendiğinde, çalışmaya katılan beden eğitimi ve spor öğretmenlerinin kıdem yılı değişkenine göre biliş ötesi farkındalık algılarını meydana getiren bilişin bilgisi ve bilişin düzenlenmesi boyutlarını oluşturan hiçbir alt faktörlerde istatistiksel olarak anlamlı farklılık bulunamamıştır $(\mathrm{p}>0.05)$. 
Tablo 7. Kıdem yılı değişkenine göre öğretmenlerin özyeterlik algılarının karşılaştırılması

\begin{tabular}{|c|c|c|c|c|c|c|}
\hline Alt Boyutlar & $\begin{array}{c}\text { Varyansın } \\
\text { Kaynağı }\end{array}$ & $\begin{array}{l}\text { Kareler } \\
\text { Toplamı }\end{array}$ & SD & $\begin{array}{c}\text { Kareler } \\
\text { Ortalaması }\end{array}$ & $\mathbf{F}$ & $\mathbf{p}$ \\
\hline \multirow[t]{3}{*}{ Katılımı sağlama } & Gruplar arası & 8.215 & 4 & 2.054 & 1.785 & .134 \\
\hline & Gruplar içi & 185.252 & 161 & 1.151 & & \\
\hline & Toplam & 193.467 & 165 & & & \\
\hline \multirow[t]{3}{*}{ Sınıf yönetimi } & Gruplar aras1 & 3.677 & 4 & .919 & 1.155 & .333 \\
\hline & Gruplar içi & 128.163 & 161 & .796 & & \\
\hline & Toplam & 131.840 & 165 & & & \\
\hline \multirow[t]{3}{*}{ Öğretim stratejisi } & Gruplar aras1 & 8.796 & 4 & 2.199 & 1.470 & .214 \\
\hline & Gruplar içi & 240.860 & 161 & 1.496 & & \\
\hline & Toplam & 249.656 & 165 & & & \\
\hline
\end{tabular}

Tablo 7 incelendiğinde, çalışmaya katılan beden eğitimi ve spor öğretmenlerinin kıdem yılı değişkenine göre öğretmenlik mesleğine yönelik öz yeterlik algılarını meydana getiren alt boyutlarda anlamlı farklılıklar olmadığı belirlenmiştir $(\mathrm{p}>0.05)$.

Tablo 8. Kıdem yılı değişkenine göre öğretmenlerin problem çözme algılarının karşılaştırılması

\begin{tabular}{|c|c|c|c|c|c|c|}
\hline Alt Boyutlar & $\begin{array}{c}\text { Varyansın } \\
\text { Kaynağı }\end{array}$ & $\begin{array}{c}\text { Kareler } \\
\text { Toplamı }\end{array}$ & SD & $\begin{array}{c}\text { Kareler } \\
\text { Ortalaması }\end{array}$ & $\mathbf{F}$ & $\mathbf{p}$ \\
\hline \multirow[t]{3}{*}{ Aceleci yaklaşım } & Gruplar aras1 & .949 & 4 & .237 & .245 & .912 \\
\hline & Gruplar içi & 155.815 & 161 & .968 & & \\
\hline & Toplam & 156.765 & 165 & & & \\
\hline \multirow[t]{3}{*}{ Düşünen yaklaşım } & Gruplar aras1 & 1.903 & 4 & .476 & .557 & .695 \\
\hline & Gruplar içi & 137.652 & 161 & .855 & & \\
\hline & Toplam & 139.555 & 165 & & & \\
\hline \multirow[t]{3}{*}{ Kaçıngan yaklaşım } & Gruplar aras1 & 3.063 & 4 & .766 & .276 & .893 \\
\hline & Gruplar içi & 446.743 & 161 & 2.775 & & \\
\hline & Toplam & 449.806 & 165 & & & \\
\hline \multirow[t]{3}{*}{ Değerlendirici yaklaşım } & Gruplar aras1 & 7.339 & 4 & 1.835 & 1.341 & .257 \\
\hline & Gruplar içi & 220.314 & 161 & 1.368 & & \\
\hline & Toplam & 227.653 & 165 & & & \\
\hline \multirow[t]{3}{*}{ Kendine güvenli yaklaşım } & Gruplar arası & 4.661 & 4 & 1.165 & 1.561 & .187 \\
\hline & Gruplar içi & 120.168 & 161 & .746 & & \\
\hline & Toplam & 124.829 & 165 & & & \\
\hline \multirow[t]{3}{*}{ Planlı yaklaşım } & Gruplar aras1 & 5.265 & 4 & 1.316 & 1.347 & .255 \\
\hline & Gruplar içi & 157.329 & 161 & .977 & & \\
\hline & Toplam & 162.594 & 165 & & & \\
\hline
\end{tabular}

Tablo 8 incelendiğinde, çalışmaya katılan beden eğitimi ve spor öğretmenlerinin kıdem yılı değişkenine göre problem çözmeye yönelik algılarını meydana getiren alt boyutlarda anlamlı farklılıklar olmadığg belirlenmiştir ( $\mathrm{p}>0.05)$. 
Tablo 9. Eğitim seviyesi değişkenine göre öğretmenlerin bilişötesi farkındalık, öğretmen özyeterlik ve problem çözme algılarının karşılaştırılması

\begin{tabular}{|c|c|c|c|c|c|c|c|c|}
\hline & Alt-boyutlar & $\begin{array}{l}\text { Eğitim } \\
\text { Seviyesi }\end{array}$ & $\mathbf{n}$ & $\bar{X}$ & Sd & SD & $\mathbf{t}$ & $\mathbf{p}$ \\
\hline \multirow{20}{*}{$\begin{array}{l}\text { Bilişötesi } \\
\text { Farkındalık }\end{array}$} & \multirow[t]{2}{*}{ Açıklayıcı bilgi } & Lisans & 140 & 4.32 & .42 & 164 & 1.453 & .148 \\
\hline & & Y. Lisans & 26 & 4.18 & .53 & & & \\
\hline & \multirow[t]{2}{*}{ Prosedürel bilgi } & Lisans & 140 & 4.09 & .52 & 164 & 1.621 & .107 \\
\hline & & Y. Lisans & 26 & 3.91 & .54 & & & \\
\hline & \multirow[t]{2}{*}{ Durumsal bilgi } & Lisans & 140 & 4.34 & .47 & 164 & 1.137 & .257 \\
\hline & & Y. Lisans & 26 & 4.22 & .49 & & & \\
\hline & \multirow[t]{2}{*}{ Planlama } & Lisans & 140 & 4.22 & .49 & 164 & 1.528 & .128 \\
\hline & & Y. Lisans & 26 & 4.06 & .53 & & & \\
\hline & \multirow[t]{2}{*}{ İzleme } & Lisans & 140 & 4.19 & .50 & 164 & 1.779 & .077 \\
\hline & & Y. Lisans & 26 & 4.00 & .62 & & & \\
\hline & \multirow[t]{2}{*}{ Değerlendirme } & Lisans & 140 & 4.23 & .52 & 164 & .117 & .907 \\
\hline & & Y. Lisans & 26 & 4.22 & .51 & & & \\
\hline & \multirow[t]{2}{*}{ Hata ayıklama } & Lisans & 140 & 4.23 & .57 & 164 & .694 & .488 \\
\hline & & Y. Lisans & 26 & 4.15 & .62 & & & \\
\hline & \multirow[t]{2}{*}{ Bilgi yönetme } & Lisans & 140 & 4.21 & .52 & 164 & 1.504 & .135 \\
\hline & & Y. Lisans & 26 & 4.05 & .40 & & & \\
\hline & \multirow[t]{2}{*}{ Bilişin bilgisi } & Lisans & 140 & 4.25 & .42 & 164 & 1.581 & .116 \\
\hline & & Y. Lisans & 26 & 4.11 & .47 & & & \\
\hline & \multirow{2}{*}{$\begin{array}{l}\text { Bilişin } \\
\text { düzenlenmesi }\end{array}$} & Lisans & 140 & 4.22 & .47 & 164 & 1.227 & .232 \\
\hline & & Y. Lisans & 26 & 4.09 & .48 & & & \\
\hline \multirow{6}{*}{$\begin{array}{l}\text { Mesleğe } \\
\text { Yönelik } \\
\text { Özyeterlik }\end{array}$} & \multirow[t]{2}{*}{ Katılımı sağlama } & Lisans & 140 & 7.64 & 1.08 & 164 & 1.441 & .151 \\
\hline & & Y. Lisans & 26 & 7.31 & 1.07 & & & \\
\hline & \multirow[t]{2}{*}{ Sınıf yönetimi } & Lisans & 140 & 7.82 & .88 & 164 & .786 & .433 \\
\hline & & Y. Lisans & 26 & 7.67 & .89 & & & \\
\hline & \multirow[t]{2}{*}{ Öğretim stratejileri } & Lisans & 140 & 7.91 & 1.26 & 164 & 1.063 & .289 \\
\hline & & Y. Lisans & 26 & 7.63 & 1.08 & & & \\
\hline \multirow{12}{*}{$\begin{array}{l}\text { Problem } \\
\text { Çözme }\end{array}$} & \multirow[t]{2}{*}{ Aceleci yaklaşım } & Lisans & 140 & 2.56 & .98 & 164 & -1.109 & .269 \\
\hline & & Y. Lisans & 26 & 2.79 & .93 & & & \\
\hline & \multirow[t]{2}{*}{ Düşünen yaklaşım } & Lisans & 140 & 3.83 & .96 & 164 & -.537 & .592 \\
\hline & & Y. Lisans & 26 & 3.94 & .63 & & & \\
\hline & \multirow[t]{2}{*}{ Kaçıngan yaklaşım } & Lisans & 140 & 2.04 & 1.61 & 164 & -1.315 & .190 \\
\hline & & Y. Lisans & 26 & 2.50 & 1.83 & & & \\
\hline & \multirow{2}{*}{$\begin{array}{l}\text { Değerlendirici } \\
\text { yaklaşım }\end{array}$} & Lisans & 140 & 3.80 & 1.16 & 164 & 1.178 & .240 \\
\hline & & Y. Lisans & 26 & 3.50 & 1.25 & & & \\
\hline & \multirow{2}{*}{$\begin{array}{l}\text { Kendine güvenli } \\
\text { yaklaşım }\end{array}$} & Lisans & 140 & 3.71 & .90 & 164 & .152 & .879 \\
\hline & & Y. Lisans & 26 & 3.69 & .73 & & & \\
\hline & \multirow{2}{*}{ Planlı yaklaşım } & Lisans & 140 & 3.87 & 1.00 & 164 & -.054 & .957 \\
\hline & & Y. Lisans & 26 & 3.88 & .96 & & & \\
\hline
\end{tabular}

Çalışmaya katılan öğretmenlerin eğitim seviyesi değişkenine göre biliş ötesi farkındalık düzeylerinin, problem çözme becerisi ve öğretmen öz yeterlik algılarının hiçbir alt boyutunda anlamlı farklılığa ulaşılamamıştır ( $\mathrm{p}>0.05)$. 
Tablo 10. Öğretmenlerin bilişötesi farkındalık, mesleğe yönelik özyeterlik ve problem çözme algılarını oluşturan alt boyutlar arasındaki ilişkilerin karşılaştırılması

\begin{tabular}{|c|c|c|c|c|c|c|c|c|c|c|c|}
\hline $\begin{array}{l}\text { Alt } \\
\text { Boyutlar }\end{array}$ & Biliş bil. & $\begin{array}{l}\text { Bilişin } \\
\text { Düzen. }\end{array}$ & $\begin{array}{l}\text { Katıl. } \\
\text { Sağ. }\end{array}$ & $\begin{array}{l}\text { Sinıf } \\
\text { yönet. }\end{array}$ & $\begin{array}{l}\text { Öğrt. } \\
\text { Stra. }\end{array}$ & $\begin{array}{l}\text { Acele. } \\
\text { Yak. }\end{array}$ & $\begin{array}{l}\text { Düş. } \\
\text { Yak. }\end{array}$ & $\begin{array}{l}\text { Kaçın. } \\
\text { Yak. }\end{array}$ & $\begin{array}{l}\text { Değer. } \\
\text { Yak. }\end{array}$ & $\begin{array}{l}\text { Ken. } \\
\text { Güv. } \\
\text { Yak. }\end{array}$ & $\begin{array}{l}\text { Plan. } \\
\text { Yak. }\end{array}$ \\
\hline Biliş bil. & $\begin{array}{c}1.00 \\
- \\
166\end{array}$ & $\begin{array}{l}.888^{*} \\
.000 \\
166\end{array}$ & $\begin{array}{c}.494 * * \\
.000 \\
166\end{array}$ & $\begin{array}{l}.536^{*} \\
.000 \\
166\end{array}$ & $\begin{array}{c}.391 * * \\
.000 \\
166\end{array}$ & $\begin{array}{c}-.274 * * \\
.000 \\
166\end{array}$ & & & & & \\
\hline $\begin{array}{l}\text { Bilişin } \\
\text { Düzen. }\end{array}$ & & $\begin{array}{c}1.00 \\
- \\
166\end{array}$ & $\begin{array}{c}.477 * * \\
.000 \\
166\end{array}$ & $\begin{array}{c}.545^{* * *} \\
.000 \\
166\end{array}$ & $\begin{array}{c}.384 * * \\
.000 \\
166\end{array}$ & $\begin{array}{c}.289^{* *} \\
.000 \\
166\end{array}$ & & & & & \\
\hline $\begin{array}{l}\text { Katıl. } \\
\text { Sağ. }\end{array}$ & & & $\begin{array}{l}1.00 \\
- \\
166\end{array}$ & $\begin{array}{l}.681- \\
.000 \\
166\end{array}$ & $\begin{array}{c}.424 * * \\
.000 \\
166\end{array}$ & $\begin{array}{c}-.218^{* *} \\
.005 \\
166\end{array}$ & & & & & \\
\hline $\begin{array}{l}\text { Sinıf } \\
\text { yönet. }\end{array}$ & & & & $\begin{array}{c}1.00 \\
- \\
166\end{array}$ & $\begin{array}{c}.560 * * \\
.000 \\
166\end{array}$ & $\begin{array}{c}-.295^{* *} \\
.000 \\
166\end{array}$ & & & & & \\
\hline $\begin{array}{l}\text { Öğrt. } \\
\text { Stra. }\end{array}$ & & & & & $\begin{array}{c}1.00 \\
- \\
166\end{array}$ & $\begin{array}{l}-.121 \\
.119 \\
166\end{array}$ & & & & & \\
\hline $\begin{array}{l}\text { Acele. } \\
\text { Yak. }\end{array}$ & & & & & & $\begin{array}{c}1.00 \\
- \\
166\end{array}$ & $\begin{array}{c}-.256 * * \\
.001 \\
166\end{array}$ & $\begin{array}{c}.475^{* *} \\
.026 \\
166\end{array}$ & $\begin{array}{c}-.173^{*} \\
.026 \\
166\end{array}$ & $\begin{array}{l}.018 \\
.822 \\
166\end{array}$ & $\begin{array}{c}- \\
.327 * \\
.00 \\
166\end{array}$ \\
\hline $\begin{array}{l}\text { Düss. } \\
\text { Yak. }\end{array}$ & & & & & & & $\begin{array}{c}1.00 \\
- \\
166\end{array}$ & & & & \\
\hline $\begin{array}{l}\text { Kaçın. } \\
\text { Yak. }\end{array}$ & & & & & & & & $\begin{array}{c}1.00 \\
- \\
166\end{array}$ & & & \\
\hline $\begin{array}{l}\text { Değer. } \\
\text { Yak. }\end{array}$ & & & & & & & & & $\begin{array}{c}1.00 \\
- \\
166\end{array}$ & & \\
\hline $\begin{array}{l}\text { Ken. Güv. } \\
\text { Yak. }\end{array}$ & & & & & & & & & & $\begin{array}{c}1.00 \\
- \\
166\end{array}$ & \\
\hline Plan. Yak & & & & & & & & & & & $\begin{array}{c}1.00 \\
- \\
166\end{array}$ \\
\hline
\end{tabular}

Tablo 10'a göre, biliş ötesi farkındalığını oluşturan boyutlar olan biliş bilgisi ve bilişin düzenlenmesi ve alt faktörler olan açıklayıcı bilgi, prosedürel bilgi, durumsal bilgi, planlama, izleme, değerlendirme, hata ayıklama ve bilgi yöneltme ile öğretmen özyeterlik algısını oluşturan alt boyutlar olan katılım sağlama, sınıf yönetimi ve öğretim stratejileri arasında orta düzeyde, anlamlı ve pozitif ilişkiler olduğunu, ancak biliş ötesi farkındalık alt boyutları ve boyutları ile 
problem çözme algısı arasında ilişki olmadığı belirlenmiştir. Ayrıca, öğretmen özyeterlik algısı ile problem çözme algısı arasında da düşük, anlamlı ve pozitif ilişkiler bulunmuştur.

\section{Tartışma ve Sonuç}

$\mathrm{Bu}$ çalışma beden eğitimi ve spor öğretmenlerinin biliş ötesi farkındalık, problem çözme ve öğretmenlik özyeterlik alg1 seviyelerinin cinsiyet, kıdem yılı ve eğitim seviyelerine göre belirlenerek, bu özellikler arasındaki ilişki düzeyini belirlemeye yönelik olarak yapılmıştır. Yapılan bu çalışmada beden eğitimi ve spor öğretmenlerinin bilişötesi farkındalık ve öğretmen öz yeterlik algılarının yüksek olduğu, problem çözme becerilerinin ise orta düzeyde olduğu belirlenmiştir. Öğretmenlerin bilişötesi farkındalıklarının ve özyeterlik algılarının yüksek çıkmasının nedeni çalışmaya katılanların büyük bölümünün mesleki deneyiminin fazla olması, mesleklerini icra ederken benzer deneyimlere sahip olmaları ve öğretmen olabilmek için benzer eğitim sürecinden geçmiş olmaları şeklinde yorumlanabilir. Aktağ, (2017)'ın yapmış olduğu çalışmada beden eğitimi öğretmenlerinin bilişötesi farkındalık düzeyleri ve Tekkurşun (2015)'nun beden eğitimi öğretmen adayları üzerinde yaptığı çalışmada da öz yeterlik algılarını yüksek düzeyde tespit edilmişlerdir. Problem çözme düzeyinin orta seviyede çıkması ise ilginç bir bulgudur. Çünkü beden eğitimi ve spor öğretmenleri okul ortamında öğretimlerini gerçekleştirirken çeşitli sebeplerden dolayı (malzeme eksikliği, mekan sıkıntısı, ders süresince farklı görevler yerine getirilmesi isteği-okul takımları çalışma ve maçları, ortak sınavlar için gözetmenlik-vb.) farklı problem durumları ile karşı karşıya kalmaktadır. Tüm bu problemlerin istenilen şekilde çözümü için beden eğitimi öğretmenlerinin problem çözme becerilerinin yüksek düzeyde olması beklenmekteyken, çalışmada elde edilen bulgular beklenen hipotezi doğrulamamaktadır. Karamehmetoğlu (2017)'na göre problem çözme becerisinin gelişmesi meslekte geçirilen süreye değil problemle ne zaman karşılaşıldığıyla bağlıdır. Bandura (1997)’ya göre bireyler, sosyal etkileşimlere girdikçe ve bu etkileşimlerde karşılaştıkları sorunları başarılı biçimde çözdükçe daha sonraki kişilerarası ilişkilerde karşılaşacakları sorunları çözmeyle ilgili kendilerine yönelik güven geliştirecekleri kabul edilir. Benzer şekilde Temel ve Ayan (2015)'ın yaptığı çalışmada da beden eğitimi ve spor öğretmenlerinin problem çözme düzeyleri orta seviyede bulunmuştur. Çalışmaya katılan öğretmenlerin biliş ötesi farkındalık ve öğretmen öz yeterlik düzeyleri ile ilgili literatür incelendiğinde araştırmanın sonuçlarıyla örtüşen çalışmalar bulunmaktadır (Kiremitçi, 2011, 2013, 2014; Yavuz ve Memiş, 2010; Bakioğlu, AlışKüçükaydın, Karamustafaoğlu, Uluçinar-Sağır, Akman, Ersanlı, ve Çakır, 2015; Deniz, Küçük, Cansız, Akgün ve İşleyen, 2014; Tunca ve Alkın-Şahin;2014). 
Araştırma bulgularında öğretmenlerin cinsiyet, kıdem yılı ve eğitim seviyelerine göre bilişötesi farkındalık düzeyleri, problem çözme becerileri ve öğretmenlik öz yeterlik algıları arasında hiçbir alt boyutta anlamlı farklılığa ulaşılamamıştır. Bu duruma çalışmaya katılan öğretmen grubunun nitelikleri etki etmiş olabilir. Çünkü çalışmaya MEB tarafından kendi illerindeki beden eğitimi ve spor öğretmenlerine yenilenen Beden Eğitimi ve Spor Dersi Öğretim Programını tanıtmak üzere seçilen öğretmenler katılmıştır. Çalışmaya katılan bu öğretmenlerin MEB tarafından belirlenen bir takım kriterlere sahip olmaları (benzer mesleki deneyim ve mesleki başarı vb.) etki etmiş olabilir. Ancak çalışma konusu ile ilgili yapılan araştırmalar incelendiğinde benzer sonuçlara ulaşılan pek çok çalışma bulunmaktadır. Örneğin, Bağçeçi ve Kınay (2013) ve Çınar, Hatunoğlu ve Hatunoğlu (2009)'nin öğretmenler; İnel, Evrekli ve Türkmen (2011)'nin ise öğretmen adayları üzerinde yapmış oldukları çalışmalarda cinsiyete göre öğretmenlerin bilişötesi farkındalık, problem çözme ve öğretmenlik özyeterlik algılarında farklılıklar bulunmadığı belirlenmiştir. Benzer şekilde Aktağ (2017)'ın yaptığı çalışmada da kıdem yılına göre öğretmenlerin bilişötesi farkındalık düzeylerinde; Üstüner, Demirtaş, Cömert ve Özer (2009) ve Korkut ve Babaoğlan (2012)'ın yaptıkları çalışmalarda ise öğretmenlerin öz yeterlik algılarında anlamlı fark olmadığı belirlenmiştir. Bağçeci ve Kınay (2013) ise öğretmenlerin eğitim düzeylerine göre problem çözme becerisinin sadece “değerlendirici” alt boyutunda fark bulmuşlardır.

Çalışma bulguları, bilişötesi farkındalığı oluşturan alt boyutlar ile öğretmen özyeterlik algısını oluşturan alt boyutlar arasında orta düzeyde, anlamlı ve pozitif ilişkiler olduğunu göstermektedir. $\mathrm{Bu}$ sonuç beden eğitimi ve spor öğretmenlerinde bilişötesi farkındalık arttıkça, mesleklerine yönelik özyeterlik algılarının da artacağı şeklinde yorumlanabilir. Bireyin kendi performansını doğrudan etkileyecek ve yükseltecek bir yolda planlama, sıralama, izleme ve daha iyi uygulama yetisi (Schraw ve Dennison, 1994) olarak tanımlanan bilişötesi farkındalık ile beden eğitimi ve spor öğretmenlerinin kendi mesleklerini icra ederken başarılı olmalarında yine doğrudan etkisi olan özyeterlik inancı ile orta düzeyde ilişki içerisindedir. Benzer şekilde Tunca ve Alkın-Şahin (2014)'nin yapmış oldukları çalışmada da özyeterlik puanları ile bilişötesi öğrenme stratejileri alt boyutları puanları arasında ilişkilerin düşük ve orta düzeyde pozitif ve anlamlı ilişkilere ulaşmışlardır. Ancak gerçekleştirilen çalışma öğretmenlerin bilişötesi farkındalık düzeyleri ile problem çözme algıları arasında ilişki olmadığını ortaya koymuştur. Bir başka değişle, beden eğitimi ve spor öğretmenlerin problem çözme algılarının bilişötesi farkındalık düzeylerinden bağımsız olduğu sonucuna ulaşılabilir. Konu ile ilgili yapılan pek çok çalışma da ise, bu çalışmada elde edilen bulguyla çelişen sonuçlara ulaşılmıştır (Bakioğlu, 2015; Kışkır,2011; 
Demirel ve Turan, 2010; Karakelle, 2012; Kiremitçi, 2011; Özsoy, 2007; Yurdakul, 2004; Borkowski, 1989; Goos ve Galbraith, 1996).

Çalışmada ayrıca, öğretmen özyeterlik algısı ile problem çözme algısı arasında da düşük, anlamlı ve pozitif ilişkiler bulunmuştur. Bu sonuca göre beden eğitimi ve spor öğretmenlerinde problem çözme becerileri arttıkça, mesleklerine yönelik özyeterlik algılarının da artacağı söylenebilir. Öğretmen özyeterliği, kısaca öğretmenlerin kendi mesleklerinde karşılaştıkları sorunları çözmelerine olan inançları olarak tanımlanabilir. $\mathrm{Bu}$ tanımdan da anlaşılacağı üzere, öğretmenlerin mesleki özyeterlik inançları için, kendilerinin problem çözme becerilerine olan inançları da son derece önemlidir. Ancak yapılan çalışmada bu iki kavram arasındaki ilişki düşük düzeyde bulunmuştur. Literatürde çalışma bulgularını destekleyen çalışmalar bulunmaktadır. Örneğin, Yenice (2012)'nin araştırmasında öğretmen adaylarının problem çözme becerileri ile özyeterlik düzeyleri arasında orta düzeyde pozitif ve anlamlı bir ilişki bulunmuştur. Bu bulgular Altunçekiç, Yaman ve Koray (2005) tarafından yapılan çalışmayla da paralellik göstermektedir. Dolayısıyla bireylerin yapmış oldukları iş ile ilgili özyeterlik düzeyleri arttıkça problem çözme becerilerinin de yükseldiği savunulabilir.

Konu ile ilgili yapılan çalışmalar incelendiğinde bilişötesi farkındalığın düşünme becerisi, problem çözme, özyeterlik, akademik başarı gibi becerilerle ilişkili olduğu ortaya çıkmıştır. Ancak gerçekleştirilen çalışmada da olduğu gibi birçok çalışmada da bilişötesi farkındalık ile cinsiyet, eğitim durumu ve çalışma süresi gibi değişkenlerde anlamlı farklılıklara ulaşılamamıştır. Bu konuda literatür incelendiğinde yapılan çalışmaların daha çok öğrenciler üzerinde yoğunluk kazandığı gözlenmiştir. Bunun sebebi bilişötesi becerilerin gelişiminin zihinsel yeteneklerin gelişimi ile paralellik gösterdiği (Alexander, Johnson, Freygang ve Scott, 2006) ve ilk çocukluk yıllarında edinilen bilişötesi gelişimin, ilerleyen yıllarda kazanılacak olan üst düzey bilişsel becerilerin kaynağını oluşturuyor olması olabilir (Kuhn, 2000).

Bağ, Uşak, ve Caner, (2006) bilişötesi becerilerin doğal gelişim sonucunda kazanılmasını beklememek gerektiğini ve bu becerilerin kazanılmasında yapılan öğretimin etkisinin yüksek olduğundan öğretmenlerin, öğrencilerin bilişötesi becerilerinin gelişimine yardım edecek şekilde öğretimi düzenlemeleri gerektiğini bildirmişlerdir. Martinez (2006)'e göre öğretmenler bilişötesinin önemini sezgisel olarak anlamakta fakat onun birçok boyutunun olduğunun farkında olmadıklarını ve bu nedenle bilişötesinin tüm boyutlarının her yaştaki öğrenenlerle işlenmesi gerektiğini belirtmiştir. Butler ve Winne (1995) ise, öğrencilerin bilişötesi becerilerinin gelişmesi için hem bilişsel hem de bilişötesi düşünme süreçlerini yansıtacak bir modellemenin gerekliliğini vurgulamışlardır. Sonuç olarak; 21.yüzyılda küreselleşen dünya ile rekabet edebilecek bilişötesi 
farkındalık becerileri gelişmiş öğrenciler için öncelikle eğitimde yapılandırmacı öğrenme anlayışının tüm boyutlarıyla işlerlik kazanması ve bu işlerlikteki en önemli role sahip olan öğretmenlerin hem bilişsel becerileri hem de bilişötesi farkındalık becerileriyle öğrencilerine iyi bir rol model olması gerektiğine inanılmaktadır.

Sonuç olarak, yapılan çalışmanın seçilmiş bir beden eğitimi ve spor öğretmen grubu üzerinde gerçekleştirilmiş olması ve sadece ortaokulda görev yapan öğretmenler üzerinde uygulanması, çalışmanın sınırlı yanlarını oluşturmaktadır. Bundan sonra yapılacak benzer çalışmalarda bu hususların göz önünde bulundurulması, çalışılan kavramların diğer öğretmen gruplarına da uygulanarak, beden eğitimi ve spor öğretmenleri ile karşılaştırılmalarının yapılması, benzer çalışmaların beden eğitimi ve spor öğretmen adaylarına da uygulanarak, elde edilecek sonuçlara göre öğretmen yetiştirmeye dönük gerekli önlemlerin alınmasının faydalı olacağı düşünülmektedir.

\section{Kaynakça}

Akın, A. (2006). Başarı amaç oryantasyonları ile biliş ötesi farkındalık, ebeveyn tutumları ve akademik başarı arasındaki ilişkiler. Yayımlanmamış Yüksek Lisans Tezi, Sakarya Üniversitesi Sosyal Bilimler Enstitüsü, Sakarya.

Akın, A., Abacı, R. \& Çetin, B. (2007). Bilişötesi farkındalık envanterinin Türkçe formunun geçerlilik ve güvenirlik çalışması. Kuram ve Uygulamada Eğitim Bilimleri, 7 (2), 655-680.

Aktağ, I., Şemşek, Ö., \& Tuzcuoğlu, S. (2017) "Determination Metacognitive Awareness of Physical Education Teachers". Journal of Education and Training Studies 5 (9), 63-69.

Altunçekiç, A., Yaman, S. ve Koray, Ö. (2005). Öğretmen adaylarının öz-yeterlik inanç düzeyleri ve problem çözme becerileri üzerine bir araştırma. ( Kastamonu ili örneği). Kastamonu Eğitim Dergisi, 13 (1), 93-102.

Alexander, J. M., Johnson, K. E., Albano, J., Freygang, T. ve Scott, B.(2006) Relations Between intelligence and the development of metaconceptual knowledge. Metacognition and Learning, 1, 51-67.

Bağçeçi, B. ve Kinay, İ. (2013). "Öğretmenlerin problem çözme becerilerinin bazı değişkenlere göre incelenmesi”. Elektronik Sosyal Bilimler Dergisi 12 (44), 335-347.

Bağ, H., Uşak, M., ve Caner, F. (2006). Üst biliş (metacognition). Akt: M. Bahar (Ed.), Fen ve Teknoloji Öğretimi. Pegem Yayınc1lik. ss.249-276

Bandura, A. (1982). Self- efficacy mechanism in human agency. American Psychologist, 37 (2), 122-147.

Bandura, A. (1986). Social Foundations of thought and action:A social cognitive teory. New Jersey: Prentice Hall. Bandura, A. (1997). Self-efficacy, the exercise of control. New York: W.H. Freeman and Company.

Bakioğlu, B., Alış-Küçükaydın, M., Karamustafaoğlu, O., Uluçınar-Sağır, Ş., Akman, E., Ersanlı, E., Çakır, R., (2015). "Öğretmen adaylarının bilişötesi farkındalık düzeyi, problem çözme becerileri ve teknoloji tutumlarının incelenmesi”, Trakya Üniversitesi Eğitim Fakültesi Dergisi, 1 (1), 22-33.

Bilen, M. (1999). Plandan Uygulamaya Öğretim. Ankara: Aydan Web Tesisleri.

Borkowski, J.G., Estrada, M.T., Mistead, M. \& Hale, C.A. (1989). General problem solving skills: relations between metacognition and strategic processing, Learning Disability Quarterly, 12(1), 57-70.

Butler, D. L., ve Winne, P.H. (1995). Feedback and Self-Regulated Learning: A Theoretical Synthesis, Review of Educational Research, 65 (3), 245-281.

Çapa, Y., Çakıroğlu, J. \& Sarıkaya, H. (2005). “The development and validation of a Turkish version of the teachers' sense of efficacy scale". Eğitim ve Bilim, 30 (137), 74-81. 
Çınar, O., Hatunoğlu, A. ve Hatunoğlu, Y. (2009). “Öğretmenlerin problem çözme becerileri”, Erzincan Eğitim Fakültesi Dergisi 11 (2), 215-225.

Demirel, M. ve Turan, A.B. (2010). "Probleme dayalı öğrenmenin başarıya, tutuma, bilişötesi farkındalık ve güdü düzeyine etkisi”, Hacettepe Üniversitesi Ĕ̆itim Fakültesi Dergisi, 38, 55-66

Deniz, D., Küçük, B., Cansız, Ş., Akgün, L., İşleyen, T. (2014) "Ortaöğretim matematik öğretmeni adaylarının üstbiliş farkındalıklarının bazı değişkenler açısından incelenmesi”, Kastamonu Eğitim Dergisi 22 (1), 305-320.

Flavell, J. H. (1979). Metacognitive and Cognitive Monitoring: A New Area of Cognitive Developmental Inquiry. American Psychologyst. 34: 906-911

Hartman, H.J. (1998). Metacognition in teaching and learning; an introduction, Instructional Science, 26, 1-3.

Heppner, P.P. \& Petersen, C.H. (1982). "The Development and implications of a personal problem solvinginventory", Journal of Counseling Psychology, 29, 66-75.

İnel, D., Evrekli, E. \& Türkmen, L. (2011) "Sınıf öğretmeni adaylarının problem çözme becerilerinin araştırılması". Pamukkale üniversitesi Eğitim Fakültesi Dergisi, 29 (1), 167-178.

Gelbal, S. (1991). "Problem çözme". Hacettepe Üniversitesi Ĕgitim Fakültesi Dergisi, 6, 167-173.

Goddard, R. G., Hoy, W.K., \& Woolfolk Hoy, A. (2004). "Collective efficacy; Thearetical development, empirical evidence, and future directions". Educational Researchers, 33, 2-13.

Goos, M. \& Galbraith, P. (1996). "Do it this way! Metacognitive strategies in collaborative mathematical problem solving", Educational Studies in Mathematics, 30(3), 229-260.

Gürleyük, G.C. ve Sucu, Ö.H. (2014) "Üniversite öğrencilerinin bilişüstü farkındalık düzeyinin incelenmesi”, Erciyes Üniversitesi örneği, Milli Eğitim Dergisi, 43 (201), 109-124.

Karakelle, S. ve Saraç, S. (2007) “Çocuklar için Üst Bilişsel Farkındalık Ölçeği (ÜBFÖ-Ç) A ve B formları: Geçerlik ve güvenirlik çalışması". Türk Psikoloji Yazıları, 10(20), 87- 103.

Karakelle, S. (2012). "Üst bilişsel farkındalık, zeka, problem çözme algısı ve düşünme ihtiyacı arasındaki bağlantılar", Eğitim ve Bilim Dergisi, 37 (164), 237-250.

Karamehmetoğlu, M. (2017). "Beden eğitimi öğretmenlerinin duygusal zeka düzeylerinin mesleki öz yeterlik ve problem çözme becerilerini belirlemedeki rolünün incelenmesi” Marmara Üniversitesi Eğitim Bilimleri Enstitüsü, Yayımlanmamış Yüksek Lisans Tezi, İstanbul.

Kışkır, G. (2011). Öğretmen adaylarının bilişötesi farkındalık düzeyleri ile problem çözme becerileri arasındaki ilişkinin incelenmesi, Atatürk Üniversitesi Eğitim Bilimleri Enstitüsü, Yayımlanmamış Yüksek Lisans Tezi, Erzurum.

Kiremitçi, O. (2011). "Beden eğitimi öğretmen adaylarının üstbilişsel farkındalık ve problem çözme becerileri arasındaki ilişkinin incelenmesi”, Selçuk Üniversitesi Beden Ĕgitimi ve Spor Bilimleri Dergisi, 13 (1), 9299.

Kiremitçi, O. (2013). "Beden eğitimi ve spor yüksekokulu öğrencilerinin çoklu zeka alanlarının üstbilişsel farkındalık ve problem çözme becerilerini belirlemedeki rolü”, Spor Bilimleri Dergisi 25 (3), 118-126.

Kiremitçi, O. (2014). "Beden eğitimi ve spor yüksekokulu öğrencilerinin üstbilişsel farkındalık düzeyleri üzerine bir inceleme", Pamukkale Journal of Sport Sciences, 4, (3), 29-40.

Korkut, k. ve Babaoğlan, E. (2012). "Sınıf öğretmenlerinin öz yeterlik inançları", Uluslararası Yönetim İktisat ve İsletme Dergisi, 8 (16), 269-282.

Kruger, L. J. (1997). "Social support and self-efficacy in problem solving among teacher assistance teams and school staff". Journal of Educational Research, 90 (3), 164-168.

Kuhn, D. (2000). "Metacognitive development". Current Direction in Psychological Science, 9 (5), 178-181.

Martinez, M.E. (2006). What Is Metacognition? Phi Delta Kaplan, 67; 696-699.

MEB, (2018) Güncellenen öğretim programlarına http://mufredat.meb.gov.tr adresinden 20 Ocak 2018 tarihinde ulaşılmışıır.

Miller, M. \& Nunn, G. D. (2011). Using group discussion to improve social problem solving and learning. Education, 121 (3). 470-475.

Morgan, C.T. (1999). Psikolojiye Giriş.(13. Baskı). Hüsnü Arıı ve diğerleri (Çev.) Ankara. Meteksan Yayıncılık.

Özkan, Ö., Tekkeya, C., \& Çakıroğlu, J. (2002). "Fen bilgisi aday öğretmenlerin fen kavramlarını anlama düzeyleri, fen öğretimine yönelik tutum ve öz-yeterlik inançları”, V. Fen Bilimleri Kongresi, ODTÜ, Ankara. 
Özsoy, G. (2007). İlköğretim 5. Sinufta üstbilişsel öğretimin problem çözme başarlsına etkisi, Gazi Üniversitesi Eğitim Bilimleri Enstitüsü, Yayımlanmamış Doktora Tezi, Ankara.

Pintrich, P. R. (2002) The role of metacognitive knowledge in learning, teaching, and assessing, Theory into Practice, 41(4), 219-225.

Sapanc1, M. (2010). Güzel sanatlar eğitimi öğrencilerinin bilişüstü farkındallk düzeyleri ve öğretmenlik mesleğine yönelik öz yeterlik inançlarının incelenmesi, Abant İzzet Baysal üniversitesi Sosyal Bilimler Enstitüsü, Yayımlanmamış Yüksek Lisans Tezi, Bolu.

Senemoğlu, N. (1997). Gelişim, Öğrenme ve Öğretim. Ankara: Ertem Matbaacıllk.

Schraw, G. \& Dennison, R. S. (1994). "Assessing metacognitive awareness". Contemporary Educational Psychology, 19 (4), 460-475.

Schriver, M., \& Czerniak, C. M. (1999). "A comparison of middle and junior high science teachers levels of efficacy and knowledge of developmentally appropriate curriculum and instruction", Journal of Science Teacher Education, 10 (1), 21-42.

Schunk, D. H. (1989). "Self-efficacy and achievement behaviors". Educational Psychology Review, 1, 173-208.

Siswati, B. H. ve Corebima, A. D. (2017). "The Effect of Education Level and Gender on Students' Metacognitive Skills in Malang, Indonesia". Advances in Social Sciences Research Journal, 4(4) 163-168.

Şahin. N., Şahin, N. H. \& Heppner, P.P (1993). "Psychometric properties of the problem solving inventory in a group of turkish university students". Cognitive Therapy and Research, 17 (4), 379-396.

Şara, P. (2012). Sinıf öğretmeni adaylarının öğrenme ve ders çalışma stratejileri, problem çözme becerileri ve denetim odağı düzeylerinin çeşitli değişkenler açısından incelenmesi. Yayımlanmamış Doktora Tezi. Dokuz Eylül Üniversitesi Eğitim Bilimleri Enstitüsü, İzmir.

Tavşancıl, E. (2006). Tutumların Ölçülmesi ve SPSS ile Veri Analizi. Ankara: Nobel Yayın Dağıtım.

Tekkurşun, G. (2015). "Beden eğitimi öğretmeni adaylarının öz yetrlik inançlarının incelenmesi” Yayımlanmamış Yüksek Lisans Tezi. Gazi Üniversitesi Eğitim Bilimleri Enstitüsü, Ankara.

Temel, V., ve Ayan, V. (2015). "Beden eğitimi öğretmenlerinin problem çözme becerileri". KMÜ Sosyal ve Ekonomik Araştırmalar Dergisi, 17 (29); 70-76.

Tschannen-Moran, M. \& Woolfolk Hoy, A. (2001). "Teacher efficacy: Capturing an elusive construct”. Teaching and Teacher Education, 17, 783-805.

Tunca, N. ve Alkın-Şahin, S. (2014).’Öğretmen adaylarının Biliş̧̈tesi öğrenme stratejileri ile akademik öz yeterlik inançları arasındaki ilişki", Anadolu University Journal of Educational Sciences International 4 (1), 47 55 .

Turan, H. (2010). Sinıf öğretmenlerinin yapılandırmacı özelliği ile yaratıcı düşünme, problem çözme becerileri ve eleştirel düşünme eğilimleri arasındaki açıklayıcı ilişkiler örüntüsü, Yıldız Teknik Üniversitesi Sosyal Bilimler Enstitüsü, Yayınlanmamış Doktora tezi, İstanbul.

Üstüner, M., Demirtaş, H., Cömert, M., ve Özer, N. (2009). "Ortaöğretim öğretmenlerinin öz yeterlik algıları”, Mehmet Akif Ersoy Üniversitesi Ĕ̈itim Fakültesi Dergisi, 9 (17), 1-16.

Vrieling, E., Bastiaens, T. ve Stijnen, S. (2012). "Effects of increased self-regulated learning opportunities on student teachers' motivation and use of metacognitive skills", Australian Journal of Teacher Education, 37(8), 101-117.

Yavuz, D. ve Memiş, A. (2010). "Investigation of Self-Efficacy Perception and Metacognitive Awareness of Prospective Teachers". The International Journal of Research in Teacher Education 2010, 1(1):12-27

Yenice, N. (2012). "Öğretmen adaylarının öz-yetrlik düzeyleri ile problem çözme becerilerinin incelenmesi", Elektronik Sosyal Bilimler Dergisi 11 (39), 36-58.

Yurdakul, B. (2004). Yapılandırmacı öğrenme yaklaşımının öğrenenlerin problem çözme becerilerine, biliş̧̈tesi farkındalık ve derse yönelik tutum düzeylerine etkisi ile ögrrenme sürecine katklları, Hacettepe Üniversitesi Sosyal Bilimler Enstitüsü, Yayımlanmamış Doktora Tezi, Ankara.

Bilgi Notu: Bu çalışma 12-14 Eylül 2017 tarihinde Portekiz/Porto'da düzenlenen "3rd International Conference On Ljfelong Educatjon and Leadershjp For All" isimli kongrede sözel sunum olarak sunulmuştur. 